\title{
Effectiveness of Garlic (Allium sativum) as Antimicrobial Agent against Bacteria Causing Urinary Tract Infection
}

\author{
Muhammad Zuhal Darwis, Lisa Yuniati and Arina F. Arifin \\ Faculty of Medicine, Universitas Muslim Indonesia, Makassar 90231, Indonesia
}

\begin{abstract}
Background: Urinary tract infection (UTI), is caused by pathogen bacteria, such as: Staphylococcus aureus, Escherichia coli, Klebsiella pneumoniae, Pseudomonas aeruginosa, and Proteus sp. The emergence of antibiotic resistance, leads to treatment failure in some cases. One strategy to overcome this is using alternative therapies, one of them by using herbal plants, namely garlic (Allium sativum) which has antimicrobial effects. Aim: To determine the effectiveness of garlic extract against bacteria that causes UTI. Methods: The study used experimental in vitro method; Using garlic extract with $50 \%$ \& $80 \%$ (5 \& 8 gr garlic extract in $10 \mathrm{~mL}$ aquades as a solvent) concentration and amoxicillin as positive control which then dripped on the medium growth of bacteria's culture, then measured diameter of the minimum inhibit zone that formed. Results: The inhibitory zone diameter of $50 \%$ garlic extract showed intermediate results in Pseudomonas aeruginosa with a diameter of $13.17 \mathrm{~mm}$, and is not sensitive to other bacteria. Concentration at $80 \%$ showed sensitive results in Pseudomonas aeruginosa and Escherichia coli with diameter $17.27 \mathrm{~mm} \& 15.5$ $\mathrm{mm}$, the result is almost equivalent compared with amoxicillin, with diameter $20.38 \mathrm{~mm} \& 24.23 \mathrm{~mm}$. Conclusion: Garlic extracted with $80 \%$ concentration has antimicrobial effect against Pseudomonas aeruginosa and Escherichia coli.
\end{abstract}

Key words: Garlic extract, antimicrobial, urinary tract infection.

\section{Introduction}

Urinary tract infection is a condition that cannot be ignored because the incidence is still quite high, which is about $5.2 \%$ of patients who went to a general practisioner, 0.5 to $1 \%$ showed symptoms of urinary tract infection. The incidence rate in adult women is $5 \%$ more than men and children, while in elderly people it can reach 20-50\% [1]. Urinary tract infections are mainly caused by Gram-negative bacteria such as Escherichia coli, Klebsiella, Pseudomonas; Positive Gram such as Staphylococcus aureus; and some fungi and viruses. Currently, the therapies used in controlling the morbidity, disability and mortality caused by infectious diseases are used antibiotics (antimicrobials). Antibiotics are used for UTI therapy such as ampicillin, amoxicillin and aztreonam [2]. However, in reality many patients do not improve after being given antibiotics. One of the factors that underlies this is the emergence of bacterial

Corresponding author: Lisa Yuniati, M.D., lecturer, research fields: infectious disease and dermatovenerology. resistance to certain types of antibiotics [3]. There are many strategies to face antimicrobial resistance, such as using higher class of antibiotic, combination therapies, and using alternative therapy. Alternative therapy using natural ingredients has attracted many researchers in medicine because of therapeutic effectiveness, ease of availability, and less adverse effect [4]. One of natural ingredients that can act as antimicrobial is garlic. Garlic contains many antimicrobial substances such as: allicin, ajoene, atsiri oil, etc., which are an effective antimicrobial agent, even for resistant strains [3].

\section{Method and Materials}

\subsection{Plant Collection and Preparation}

The garlic (Allium sativum) cloves were supplied from the local markets. For extract preparation, the dried garlic material $(500 \mathrm{gr}$ ) was soaked with $2 \mathrm{~L}$ of $70 \%$ ethanol for 3-4 days, after maceration the methanolic extract was dried by oven with temperature $40-50{ }^{\circ} \mathrm{C}$ until the residual solvent 
vanished, the extract was stored under sterile conditions, protected from light in a dry and cool place at $-20{ }^{\circ} \mathrm{C}$ until use [5].

\subsection{Preparation of Standard Dilutions of Garlic} Extract

The dilutions were prepared by using aquades as a solvent and by using 5 and 8 gr from the extract, then dilute it with $10 \mathrm{~mL}$ aquades to get the final concentrations 50 and $80 \%$.

\subsection{Growth Medium Preparation}

Nutrient agar was the chosen growth medium for this research. Culture medium are prepared according to the producing companies instructions and sterilized in autoclave at $121^{\circ} \mathrm{C}$ under pressure of 15 PSI. After incubation at $37{ }^{\circ} \mathrm{C}$ for $24 \mathrm{hrs}$, the medium used to culture bacteria for this study.

\subsection{Bacteria Culture}

Bacteria were activated by re-culturing on nutrient agar and kept in the incubator for $24 \mathrm{hrs}$ at $37^{\circ} \mathrm{C}$, then sterilize tubes were transferred containing heart infusion broth, then placed in the incubator for 24-72 hrs at $37^{\circ} \mathrm{C}$.

\subsection{Garlic Extracts Activity Test Well Diffusion} Method Screening

Screening of the anti-bacterial activity was performed by disc diffusion technique. Nutrient agar plates were seeded with $0.1 \mathrm{~mL}$ of the standardized inoculums of bacteria. The inoculums were spread evenly over plate with sterile glass spreader. After that, paper discs were soaked in garlic extract dilution with concentration of $50 \& 80 \%$ and amoxicillin dilution as positive control for few minutes, after the dilution has been absorbed in paper disc, then paper disc was placed in seeded plate. The inoculated plates were incubated at $37{ }^{\circ} \mathrm{C}$ for 24 hours and zone of inhibition diameter was measured in millimeter ( $\mathrm{mm})$.

\section{Results}

After the garlic activity test, the minimum inhibitory zones that formed are measured with caliper in millimeter. Then, the results is categorized by standard interpretation of minimum inhibitory zone, which are resistant if the diameter is $12 \mathrm{~mm}$, intermediate if $13-14 \mathrm{~mm}$, and sensitive if $15 \mathrm{~mm}$ [5]. From Table 1 the results of garlic activity test are resistant in Staphylococcus aureus with diameter $10.32 \mathrm{~mm}$ and $10.72 \mathrm{~mm}$ in $50 \& 80 \%$ garlic concentration, resistant in Escherichia coli with diameter $9.17 \mathrm{~mm}$ in $50 \%$ garlic concentration, and sensitive in $80 \%$ concentration with diameter $15.5 \mathrm{~mm}$, resistant in Klebsiella pneumonia with diameter 7.65 $\mathrm{mm}$ and $7.16 \mathrm{~mm}$ in $50 \& 80 \%$ garlic concentration, intermediate in Pseudomonas aeruginosa with diameter $13.17 \mathrm{~mm}$ in $50 \%$ garlic concentration and sensitive in $80 \%$ concentration with diameter 17.27 $\mathrm{mm}$, resistant in Proteus sp. with diameter $6.89 \mathrm{~mm}$ and $7.53 \mathrm{~mm}$ in $50 \& 80 \%$ garlic concentration. In figure 1 we can see the inhibition zone formed in nutrient agar medium. The larger inhibition zone that formed means the more effective of garlic extract against Escherchia coli and Pseudomonas aeruginosa. The inhibition zone is compared with amoxicillin as positive control.

\section{Discussion}

The increasing resistance rate against many antibiotics in community has led to a demand for new herbal agent that may be used to decrease the spread of these bacteria. Many strategies were used to fight against resistance bacteria, one of them is using alternative therapy by utilizing natural resource, such as garlic that has antimicrobial properties [3].

In present study we analyze the effectiveness of garlic against bacteria causing urinary tract infection, such as: Staphylococcus aureus, Escherichia coli, Klebsiella pneumoniae, Pseudomonas aeruginosa, and Proteus sp. The result showed garlic extracts with 
Table 1 Results of garlic sensitivity test compared with amoxicillin against bacteria causing urinary tract infection.

\begin{tabular}{|c|c|c|c|c|c|c|}
\hline Bacteria & $\begin{array}{l}\text { Diameter of } \\
\text { inhibitory zone }(\mathrm{mm}) \\
\text { concentration } 50 \%\end{array}$ & Interpretation & $\begin{array}{l}\text { Diameter of inhibitory } \\
\text { zone (mm) } \\
\text { concentration } 80 \%\end{array}$ & Interpretation & $\begin{array}{l}\text { Diameter of } \\
\text { inhibitory zone } \\
(\mathrm{mm}) \text { amoxicilin }\end{array}$ & Interpretation \\
\hline $\begin{array}{l}\text { Staphylococcus } \\
\text { aureus }\end{array}$ & 10.32 & Resistant & 10.72 & Resistant & 23.95 & Sensitive \\
\hline Escherichia coli & 9.17 & Resistant & 15.5 & Sensitive & 26.67 & Sensitive \\
\hline $\begin{array}{l}\text { Klebsiella } \\
\text { Pneumonia }\end{array}$ & 7.65 & Resistant & 7.16 & Resistant & 16.68 & Sensitive \\
\hline $\begin{array}{l}\text { Pseudomonas } \\
\text { Aeruginosa }\end{array}$ & 13.17 & Intermediate & 17.27 & Sensitive & 20.71 & Sensitive \\
\hline Proteus sp. & 6.89 & Resistant & 7.53 & Resistant & 16.68 & Sensitive \\
\hline
\end{tabular}

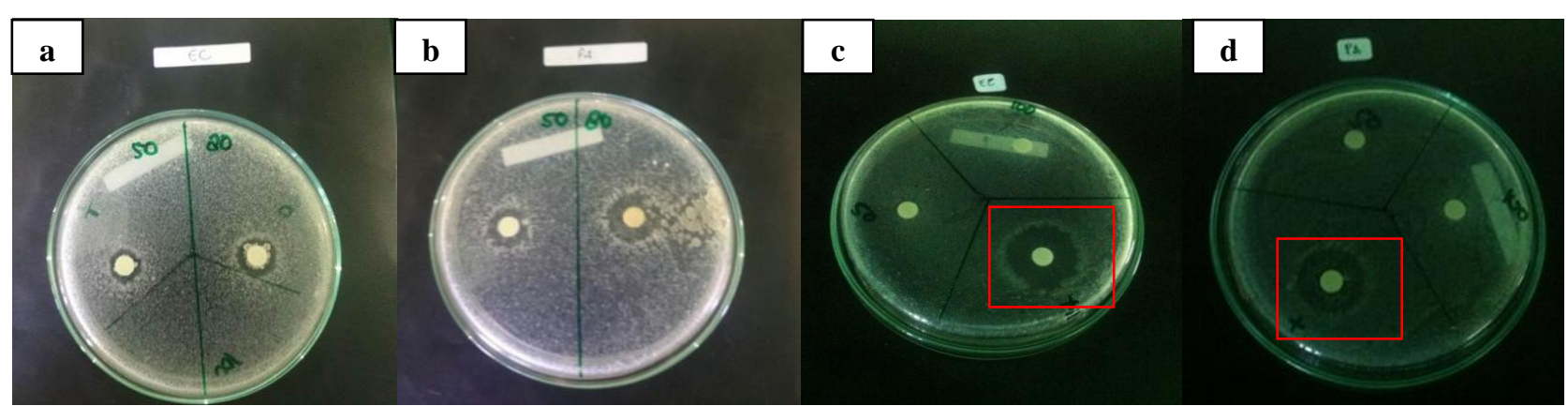

Fig. 1 (a), (b) sensitive interpretation of garlic extract for Eschericia coli and Pseudomonas aeruginosa bacteria. (c), (d) positive control of amoxicillin towards Eschericia coli and Pseudomonas aeruginosa bacteria.

concentration of $50 \& 80 \%$ are effective against Escherchia coli and Pseudomonas aeruginosa. There are huge literatures on the antibacterial effects of fresh garlic juice, aqueous and alcoholic extracts, lyophilized powder, steam distilled oil and other commercial preparations of garlic. Garlic is active even against organisms that have become resistant to antibiotics [6]. Garlic contains antimicrobial substances, such as allicin, ajoene, atsiri oil, and flavonoid. Allicin of garlic is well documented as an active ingredient in herbal medicine and has already been proved to have anti-microbial efficacy. Allicin can inhibit DNA, protein synthesis, and RNA in bacteria as a result of acetyl CoA system inhibition [7].

Ajoene can inhibit lipid membrane synthesis. Atsiri oil can discourage formation of bacteria cell membrane. Flavanoid can cause protein denaturation in bacteria [8]. Many previous studies already proof antimicrobial effect in garlic, such as Ref. [3] stated that Allium sativum is effective against uropathogens bacteria that already has resistance to antibiotic.
Another study also showed that Allium sativum also is effective against certain bacteria such as: Staphylococcus aureus, Salmonella thypii, and even Helicobacter pylori in gastric ulcer [9]. Therefore Allium sativum has considerable sensitivity against some bacteria that causes urinary tract infection. There are some factors that can disrupt the results of this research such as: contamination during storing, inoculation, and incubation, $\mathrm{pH}$, temperature, and etc. [10], which is why we need further research and another investigation of Allium sativum antimicrobial effect. So we can explore more on potential of Allium sativum as a substitute of antibiotic in near future.

\section{Conclusions}

It is concluded from this research that garlic extract (Allium sativum) contains many antimicrobial substances such as allicin, ajoene, atsiri oil, and flavonoid. It was proved by in vitro experiment that garlic with $80 \%$ concentration has antimicrobial effect against some of the bacteria that causes urinary tract 
infection, which are Pseudomonas aeruginosa and Escherichia coli.

\section{References}

[1] Abdelmalak, J. B., et al. 2008. "National Kidney and Urologic Diseases Information Clearinghouse: Urinary Tract Infections in Adults." Accessed January 102018. http://www.urologyhealth.org/urology/index.cfm?article= 47.

[2] Kasper, D. L., et al. 2005. Harrison's Principle of Internal Medicine. 16th ed. USA: McGraw Hill.

[3] Kumar, A., and Sharma, V. 2009. "Antibacterial Activity of Allicin from Allium Sativum against Antibiotic Resistant Uropathogens." The Internet Journal of Infectious Diseases 8 (1).

[4] Vishwakarma, A. P., Vishwe, A., Sahu, P., and Chaurasiya, A. 2013. "Magical Remedies of Terminalia Arjuna (ROXB)." International Journal of Pharmaceutical Archive 2: 189-201.

[5] Khashan, A. A. 2014. "Antibacterial Activity of Garlic
Extract (Allium sativum) against Staphylococcus Aureus in Vitro." Global Journal of Bio-Science and Biotechnology 3 (April): 346-8.

[6] Jezowa, L., Rafinski, T., and Wrocinski, T. 1996. "Investigations on the Antibiotic Activity of Allium sativum L." Herba Pot. 12: 3-13.

[7] Amagase, H. 2006. "Clarifying the Real Bioactive Constituents of Garlic." The Journal of Nutrition 136: $716 \mathrm{~S}-25 \mathrm{~S}$

[8] Gulfraz, M., Imran, M., and Khadam, S. 2014. "A Comparative Study of Antimicrobial and Antioxidant Activities of Garlic (Allium sativum L.) Extracts in Various Localities in Pakistan." Afr J Plant Sci. Accessed January $\quad 15 \quad 2018$ http://www.academicjournals.org/articlee/article1403521 690_Gulfraz\%20et\%20al.pdf.

[9] Setiawan, V. W., Yu, G. P., Lu, Q. Y., et al. 2005. "Allium Vegetables and Stomach Cancer Risk in China." Asian Pac. Cancer Prev. 6: 387-95.

[10] Schlegel, G. H., and Karin. 1994. Mikrobiologi Umum: Gajah Mada University Press. 